\title{
Politeness Strategies of Javanese Woman Characters in Novel 'Gadis Pantai' Written by Pramoedya Ananta Toer
}

\author{
Sri Sugiharti ${ }^{1}$, M. R. Nababan ${ }^{2}$, Riyadi Santosa ${ }^{3}$, Supana $^{4}$ \\ \{ srisugihartiwismono@gmail.com ${ }^{1}$, amantaradja@yahoo.com ${ }^{2}$, riyadisantosa@ staff.uns.ac.id ${ }^{3}$, \\ supana_77@yahoo.com ${ }^{4}$ \} \\ Doctorate Program in Linguistics, Universitas Sebelas Maret, Jl. Ir. Sutami 36A, Surakarta 57126, \\ Indonesia ${ }^{1234}$
}

\begin{abstract}
Employing the concept proposed by Brown and Levinson, this study aims to unfold politeness strategies used by Javanese women characters in novel 'Gadis Pantai' written by Pramoedya Ananta Toer. Furthermore, it is significant to recognize the motivation of the use of politeness strategies by the Javanese women characters in dialogues as it will reveal the way they resort to particular politeness strategies in certain circumstances of relation of power, distance, and imposition in the novel that chiefly depicts the social life of Javanese women in the colonial era. It is a qualitative research with a case study approach. The data are in the form of utterances containing politeness strategies of Javanese women characters in the novel. The data were collected by document analysis and were analyzed by domain, taxonomy, componential and cultural theme analysis. The result shows that the women characters in the novel resort to positive, baldon record, and negative politeness, in order from the highest frequency to the lowest. Positive politeness is embodied in assertive, directive, expressive and commissive speech acts. Next, bald-on record politeness is found in directive, assertive and expressive speech acts. Last, Negative politeness is represented in directive, assertive and expressive speech acts. The study concludes that the use of politeness strategies is motivated by various power and distance relations. The Javanese women characters are found to opt for a particular type of politeness strategy in the circumstance of a certain power and distance relation with the partner of conversation.
\end{abstract}

Keywords: Linguistic Composition, Mandailing Cultural Characteristics, OnangOnang Song, Relevance of Indonesian Language Learning

\section{Introduction}

Hamila [1] affirms that all of Pramoedya's novels depict stories of social injustices in Javanese cultures. The social injustices comprise among others of marginalization of women, conflict of social class, and discrimination of race and social class. However, Rahutami [2] further specifies that Pramoedya's works are all about the struggle of social class in Javanese cultures. Pramoedya is said to be a humanitarian and his ideology is manifested in his novels in the way he portrays the struggle of low-class social groups in the colonial era in Java. This suggests that the main theme of all of his novels is on the conflict or discrimination of social class, rather than on the discrimination or marginalization of women. 
In addition to that, 'Gadis Pantai' is an instance of Pramoedya's novel that many may assume to be an embodiment of his critics on gender discrimination. Certainly, it is not surprising that many will likely presume as such since the title of the novel seems to suggest the assumption. Nevertheless, according to Mandiri [3], the ideology narrated in the novel is the manifestation of the feudalism cruelty towards the low-class Javanese people, in other words, the powerful versus the powerless. Again, this is in accordance with the notion unfolded by Hamila [1] and Rahutami [2] earlier. It is interesting that Pramoedya framed the life of woman characters in the novel in the context of power relation with other characters, instead of in the context of gender relation within the society. However, it does not therefore entail that there is no depiction of gender discrimination at all in the story. It is just manifested in the realm of power relation.

The portrayal of woman characters interacting with other characters of various power levels in the story is manifested through verbal and non-verbal acts. However, it is the verbal acts that are interesting to analyze. As traditionally believed, Javanese people are known for their politeness in interaction, especially in the way they show it through their polite utterances in a conversation. As Brown \& Levinson [4] asserts, politeness strategies in a conversation are manifestation of people's attitude in dealing with the power of their partners of conversation. Other than to power relation, politeness strategies are also naturally responses to various distance relations, between the speaker and the hearer. According to Brown \& Levinson [4], the aspect of distance covers two concepts: social distance and affect distance. Social distance refers to the distance of social position of speaker and hearer. Affect distance refers to emotional and personal distance between speaker and hearer.

Therefore, this study attempts to classify the type of politeness strategies adopted by Javanese woman characters in the novel and also to unfold the influence of power and distance relation in the use of certain politeness strategies. In other words, it can be assumed that politeness strategies opted by Javanese woman characters in novel 'Gadis Pantai' are markers of certain power and distance relations with other characters in the novel. Next, such analysis will lead to the social life description of woman characters in novel 'Gadis Pantai' in relation to the context of power and distance in the colonial era in Java.

This study differs in some ways with previous similar studies. For instance, Smith-Hefner [5], Hobbs [6], Aydinoglu [7], Maros and Rosli [8] studied on the politeness strategies of different gender, with women being the main object of study. In essence, they analyzed how different gender motivates different choice of politeness strategies. It means that they attempted to capture the significance of gender aspect in the choice of politeness strategies. In contrast, even though this study analyzes politeness strategies used by women characters in novel 'Gadis Pantai', the study does not specifically attend to gender aspect in the aspect of analysis. Instead, this study attempts to explain the influence of power and distance relation on the choice of politeness strategies produced by women characters as this study seeks to explain the relation of power and Javanese women in colonial era.

\section{Research Methods}

This study employs qualitative paradigm with embedded case study approach. The source of data and data were sampled by purposive sampling. The data were collected by using document analysis. The source of data is printed version of novel 'Gadis Pantai' written by Pramoedya Ananta Toer. The data are all of utterances of all woman characters in the novel that 
contain politeness strategies. The woman characters in the novel are Gadis Pantai as the main character, Emak (mother of Gadis Pantai) and also Bujang Wanita (the woman maid that serves Gadis Pantai).

In addition to that, this research also benefits from the techniques of analysis of ethnographic study, namely domain analysis, taxonomy analysis, componential analysis, and cultural theme analysis. First, the domain of this study is the configuration of relation of power of the speaker (SP) and the hearer (HP), of social distance (SD) and affect distance (AD) between hearer and speaker, and also the range of imposition (R) in every dialogue that contains utterances of politeness strategies produced by woman characters in the novel. The existence of power on the part of speaker (SP) or hearer (HP), the presence of social distance (SD) and/or affect distance (AD) between speaker and hearer, and the presence of imposition are materialized with symbol ' + ' and the absence of them are symbolized with ' - '.

Second, the taxonomy analysis was realized in classifying the type of politeness strategies based on the underlying theory of Politeness Strategies proposed by Brown and Levinson [4] and also the types of speech acts of the data based on the underlying theory of speech acts proposed by Searle [9]. Third, the componential analysis was conducted in revealing the relation between configuration of power, distance, and imposition (context) in a conversation, and type of politeness strategies produced by the speaker as well as the type of speech acts realized. Finally, the cultural values of the found norms were elaborated.

\section{Results and Discussion}

\subsection{Configuration of Relation of Power, Distance, and Range of Imposition in the Dialogues of Javanese Women Characters in Novel 'Gadis Pantai'}

There are thirteen configurations of power, distance, and range of imposition between speaker and hearer in all dialogues in which Javanese woman characters produce utterances that contain politeness strategies in the novel. They are, in order from the most frequent to the least, -SP+HP/+SD-AD/-R, +SP-HP/+SD-AD/+R，-SP+HP/+SD-AD/+R，+SP-HP/+SD-AD/-R，$\mathrm{SP}+\mathrm{HP} /+\mathrm{SD}+\mathrm{AD} /-\mathrm{R}, \quad+\mathrm{SP}-\mathrm{HP} / \mathrm{SD}-\mathrm{AD} /+\mathrm{R}, \quad-\mathrm{SP}-\mathrm{HP} /+\mathrm{SD}+\mathrm{AD} /-\mathrm{R}, \quad-\mathrm{SP}-\mathrm{HP} /+\mathrm{SD}+\mathrm{AD} /+\mathrm{R}, \quad-$ $\mathrm{SP}+\mathrm{HP} /+\mathrm{SD}+\mathrm{AD} /+\mathrm{R},+\mathrm{SP}-\mathrm{HP} /-\mathrm{SD}-\mathrm{AD} /-\mathrm{R},-\mathrm{SP}+\mathrm{HP} /-\mathrm{SD}-\mathrm{AD} /+\mathrm{R},+\mathrm{SP}-\mathrm{HP} /+\mathrm{SD}+\mathrm{AD} /+\mathrm{R}$, and $-\mathrm{SP}+\mathrm{HP} / \mathrm{SD}-\mathrm{AD} /-\mathrm{R}$.

The occurrences of them involve various participants in the dialogues. For instance, in situation $\mathrm{SP}+\mathrm{HP} /+\mathrm{SD}-\mathrm{AD} /-\mathrm{R}$ (meaning the power of the speaker is nonexistent while the power of the hearer is present; the speaker and the hearer have a social distance but they are close in affect; and the imposition on the part of the hearer of the utterance is zero), the dialogues occur in which 1) the speaker is woman maid and the hearer is Gadis Pantai and 2) the speaker is Gadis Pantai and the hearer is Bendoro (a high class official said to be very close to the governor who becomes the husband of Gadis Pantai). In contrast, situation + SP-HP/+SD-AD/+R occurs when either 1) the speaker is Gadis Pantai and the hearer is woman maid or 2) the speaker is Bendoro and the hearer is Gadis Pantai.

In terms of power, Gadis Pantai is more powerful than woman maid but Bendoro is more powerful than Gadis Pantai since he is a powerful man in the government. In addition to that, it can also be said that this is the case since he is a man, although that is not always true. For instance, in situation $-\mathrm{SPHP} /+\mathrm{SD}+\mathrm{AD} /-\mathrm{R}$ and $-\mathrm{SP}-\mathrm{HP} /+\mathrm{SD}+\mathrm{AD} /+\mathrm{R}, 1$ ) the speaker is the woman maid, and the hearer is Emak or vice versa or 2) the speaker is the house maid and the hearer is the village chief. In case participant number 2 , the woman maid and the village chief 
are equal in power even though the chief is a man. Other than that, they share the same power because being a maid in Bendoro's house grants her power equal with the chief of the village. This reveals the concept of gender power not standing alone in the society that is depicted in the novel. Instead, it exists under theme of power, generally.

In relation with distance aspect in case $-\mathrm{SP}+\mathrm{HP} /+\mathrm{SD}-\mathrm{AD} /-\mathrm{R},-\mathrm{SP}+\mathrm{HP} /+\mathrm{SD}-\mathrm{AD} /+\mathrm{R},+\mathrm{SP}-$ $\mathrm{HP} /+\mathrm{SDAD} / \mathrm{R}$, and $+\mathrm{SP}-\mathrm{HP} /+\mathrm{SD}-\mathrm{AD} /+\mathrm{R}$, it is clear that Gadis Pantai and the woman maid have a social distance, yet they are close in personal affection. Therefore, the value of their AD is negative (-). However, this happens after both of them get closed. At their first few encounters, their AD stance is positive, as seen in $-\mathrm{SP}+\mathrm{HP} /+\mathrm{SD}+\mathrm{AD} /-\mathrm{R}$ and $-\mathrm{SP}+\mathrm{HP} /+\mathrm{SD}+\mathrm{AD} /+\mathrm{R}$, with woman maid being the speaker and Gadis Pantai being the hearer, and in $+\mathrm{SP}-\mathrm{HP} /+\mathrm{SD}+\mathrm{AD} /+\mathrm{R}$ with Gadis Pantai being the speaker and the woman maid being the hearer.

This shift of affect distance also happens between Gadis Pantai and his husband Bendoro. At their first encounter, when Gadis Pantai still does not feel anything for him, their AD is negative (SP+HP/+SD+AD/-R). It shifts into $-\mathrm{SP}+\mathrm{HP} /+\mathrm{SD}-\mathrm{AD} /-\mathrm{R}$ after Gadis Pantai realizes that she has started to love his husband. Nevertheless, their social distance is always present throughout the story, even though they are married. This is due to the fact that they actually belong to a different class of society: Bendoro is a priyayi (royal family) and Gadis Pantai is just a common people.

The various combinations of power, distance, and imposition in interpersonal relation between speaker and hearer in dialogues as mentioned above are found to be the basis sociolinguistic factor for the Javanese woman characters to opt for a particular politeness strategy. In the next discussion, they are systematically mapped and correlated, in manner of which circumstance produces which politeness strategy. Such a finding becomes an important factor in this research and also a strong point since that can explain and map the choice of politeness strategies of the characters based on the sociolinguistics context. Otherwise, the elaboration of determining choice of politeness strategies based on sociolinguistic context is not traced and sometimes are left out of discussion entirely as in the study of politeness strategies conducted by Iin [10], Tiani [11], Syariah, et al [12], and Ayuningrum, et al [13].

\subsection{Politeness Strategies of Javanese Woman Characters in Novel 'Gadis Pantai' and the Speech Acts as the Representation}

There are as many as 533 utterances of Javanese woman characters in the novel that contain various types of politeness strategies realized in different types of speech acts. They occur in thirteen different circumstances of power relation, distance, and range of imposition. In conjunction with that, it has been explained earlier that the configurations of power relation, distance, and range of imposition of utterances in dialogue situation motivate the choice of politeness strategies produced by Javanese woman characters in the novel. Table 3.1 below depict the mapping of the type of politeness strategies and their speech act representation in every sociolinguistic context.

Table 1. Politeness strategies and their speech act representations in various circumstances of power, distance, and range of imposition

\begin{tabular}{|c|c|c|c|c|c|c|}
\hline No & Sociolinguistic Context & Number & $\begin{array}{l}\text { Type of Politeness } \\
\text { Strategies }\end{array}$ & Number & $\begin{array}{c}\text { Type of Speech } \\
\text { Act }\end{array}$ & Number \\
\hline \multirow[t]{5}{*}{1} & \multirow[t]{5}{*}{-SP+HP/+SD-AD/-R } & \multirow[t]{5}{*}{148} & \multirow[t]{4}{*}{ Negative } & \multirow[t]{4}{*}{90} & Assertive & 81 \\
\hline & & & & & Directive & 6 \\
\hline & & & & & Expressive & 2 \\
\hline & & & & & Commissive & 1 \\
\hline & & & Bald-On Records & 34 & Assertive & 31 \\
\hline
\end{tabular}




\begin{tabular}{|c|c|c|c|c|c|c|}
\hline & & & & & \multirow[b]{2}{*}{ Directive } & \multirow{3}{*}{$\frac{3}{11}$} \\
\hline & & & & & & \\
\hline & & & Positive-Negative & 23 & Assertive & \\
\hline & & & & & Directive & 7 \\
\hline & & & & & Expressive & 4 \\
\hline & & & & & Commissive & 1 \\
\hline & & & Positive & 1 & Assertive & 1 \\
\hline \multirow[t]{8}{*}{2} & \multirow[t]{8}{*}{$+\mathrm{SP}-\mathrm{HP} /+\mathrm{SD}-\mathrm{AD} /+\mathrm{R}$} & \multirow[t]{8}{*}{117} & Bald-On records & 65 & Directive & 60 \\
\hline & & & & & Assertive & 5 \\
\hline & & & Negative & 48 & Directive & 44 \\
\hline & & & & & Expressive & 3 \\
\hline & & & & & Assertive & 1 \\
\hline & & & Positive & 3 & Directive & 2 \\
\hline & & & & & Expressive & 1 \\
\hline & & & Positive-Negative & 1 & Directive & 1 \\
\hline \multirow[t]{6}{*}{3} & \multirow[t]{6}{*}{$-\mathrm{SP}+\mathrm{HP} /+\mathrm{SD}-\mathrm{AD} /+\mathrm{R}$} & \multirow[t]{6}{*}{74} & Negative & 42 & Directive & 37 \\
\hline & & & & & Assertive & 5 \\
\hline & & & Bald-On Records & 30 & Directive & 26 \\
\hline & & & & & Assertive & 4 \\
\hline & & & Positive-Negative & 2 & Directive & 1 \\
\hline & & & & & Expressive & 1 \\
\hline \multirow[t]{11}{*}{4} & \multirow[t]{11}{*}{+ +SP-HP/+SD-AD/-R } & \multirow[t]{11}{*}{48} & Bald-On Records & 26 & Assertive & 24 \\
\hline & & & & & Directive & 1 \\
\hline & & & & & Expressive & 1 \\
\hline & & & Negative & 13 & Assertive & 8 \\
\hline & & & & & Expressive & 3 \\
\hline & & & & & Directive & 2 \\
\hline & & & Positive-Negative & 5 & Directive & 3 \\
\hline & & & & & Expressive & 1 \\
\hline & & & & & Commissive & 1 \\
\hline & & & Positive & 4 & Directive & 3 \\
\hline & & & & & Assertive & 1 \\
\hline \multirow[t]{6}{*}{5} & \multirow[t]{6}{*}{$-\mathrm{SP}+\mathrm{HP} /+\mathrm{SD}+\mathrm{AD} /-\mathrm{R}$} & \multirow[t]{6}{*}{31} & Negative & 21 & Assertive & 20 \\
\hline & & & & & Directive & 1 \\
\hline & & & Bald-On Records & 4 & Assertive & 4 \\
\hline & & & Positive & 3 & Directive & 3 \\
\hline & & & Positive-Negative & 3 & Assertive & 2 \\
\hline & & & & & Commissive & 1 \\
\hline \multirow[t]{4}{*}{6} & \multirow[t]{4}{*}{ +SP-HP/-SD-AD/+R } & \multirow[t]{4}{*}{27} & Bald-On Records & 17 & Directive & 16 \\
\hline & & & & & Expressive & 1 \\
\hline & & & Positive & 9 & Directive & 8 \\
\hline & & & & & Assertive & 1 \\
\hline \multirow[t]{4}{*}{7} & -SP-HP/+SD+AD/-R & 19 & Bald-On Records & 17 & Assertive & 14 \\
\hline & & & & & Directive & 2 \\
\hline & & & & & Commissive & 1 \\
\hline & & & Negative & 2 & Assertive & 2 \\
\hline 8 & -SP-HP/+SD+AD/+R & 15 & Bald-On Records & 14 & Directive & 12 \\
\hline & & & & & Assertive & 2 \\
\hline & & & Negative & 1 & Directive & 1 \\
\hline 9 & $-\mathrm{SP}+\mathrm{HP} /+\mathrm{SD}+\mathrm{AD} /+\mathrm{R}$ & 14 & Bald-On Records & 8 & Directive & 8 \\
\hline & & & Negative & 6 & Directive & 6 \\
\hline 10 & + SP-HP/-SD-AD/-R & 13 & Positive & 10 & Assertive & 4 \\
\hline & & & & & Directive & 3 \\
\hline
\end{tabular}




\begin{tabular}{|c|c|c|c|c|c|c|}
\hline & & & & & \multirow[b]{2}{*}{ Expressive } & \multirow{3}{*}{$\begin{array}{l}3 \\
3\end{array}$} \\
\hline & & & & & & \\
\hline & & & Bald-On Records & 3 & Assertive & \\
\hline \multirow[t]{5}{*}{11} & \multirow[t]{5}{*}{$-\mathrm{SP}+\mathrm{HP} /-\mathrm{SD}-\mathrm{AD} /+\mathrm{R}$} & \multirow[t]{5}{*}{12} & \multirow[t]{3}{*}{ Positive } & \multirow[t]{3}{*}{8} & Directive & 6 \\
\hline & & & & & Assertive & 1 \\
\hline & & & & & Expressive & 1 \\
\hline & & & \multirow[t]{2}{*}{ Bald-On Records } & \multirow[t]{2}{*}{4} & Directive & 3 \\
\hline & & & & & Assertive & 1 \\
\hline \multirow[t]{2}{*}{12} & \multirow[t]{2}{*}{$+\mathrm{SP}-\mathrm{HP} /+\mathrm{SD}+\mathrm{AD} /+\mathrm{R}$} & \multirow[t]{2}{*}{9} & Bald-On Records & 7 & Directive & 7 \\
\hline & & & Negative & 2 & Directive & 2 \\
\hline \multirow[t]{4}{*}{$\overline{13}$} & \multirow[t]{3}{*}{-SP+HP/-SD-AD/-R } & \multirow[t]{3}{*}{5} & \multirow[t]{2}{*}{ Positive } & 4 & Assertive & 3 \\
\hline & & & & & Directive & 1 \\
\hline & & & Bald-On Records & 1 & Assertive & 1 \\
\hline & TOTAL & 533 & & 533 & & 533 \\
\hline
\end{tabular}

From table 3.2, in general, four types of politeness strategies are spotted to be found in novel 'Gadis Pantai'. From the biggest in manifestation to the least, they are negative politeness (225), bald-on records (222 data), positive politeness (42 data), and positive-negative ( 34 data). These findings are different from another similar research conducted by Iin [10], Tiani [11] [14], Syariah, et al [12], Metiadini, et al [15] and Mudassir and Adriana [16]. Their findings on politeness strategies are based on underlying theory of politeness proposed by Leech [17]. In such a theory, the term strategy is not used. Instead, Leech adopts the term maxims to refer to the principle of politeness in conversation. This categorization is a little confusing and less systematical compared to the categorization proposed by Brown and Levinson, who correlate their categorizations of politeness strategies to the basic concept of face to make it more comprehensive and holistic.

As the most prominent in terms of occurrences, Negative Politeness Strategy persists mostly in circumstance in which the speaker is more powerful than the hearer (+SP/-HP). Other condition that motivates the use of this strategy is distance factor. In situation in which either social distance or affect distance exist, or both social distance and affect distance exist, the use of Negative Politeness is more opted. The last determinant of this strategy, after the first two aspects, is the imposition of the utterance.

However, this is oftentimes overshadowed by the adherence to the power and distance relation alone. This strategy is materialized in the novel in some fashions such as giving a deference to the hearer or lowering own self to raise the hearer as the most frequent in data, apologizing, and asking the hearer of what she/he wants realized in assertive, directive, and expressive speech acts. Giving deference or honorifics to the hearer, who are more powerful and/or higher in social class than speaker, and/or lowering speaker own self in order to raise the hearer are Javanese fashion of politeness.

This is in conjunction with the result finding of research on Javanese politeness prominent characteristics conducted by Nadar [18]. He found that Javanese people tend to use honorifics on their partner of conversation in regard to his/her power and social class and also that Javanese people tend to lower own self in order to respect the hearer.

Example 1:

Gadis Pantai : "Jangan menggunakan sahaya itu, Mbok."

Woman maid: "Sahaya hanya bujang, Mas Nganten."

In the example 1 above, the woman maid applies two markers of negative politeness at once realized in assertive stating speech act. First, she uses self-call 'sahaya'. This word means the 
same with 'saya' or 'I' but in more lowering tone. It means that when someone in Javanese culture uses that word, it means that the speaker feels that his/her social class or power is lower than the hearer. Second, the woman maid calls Gadis Pantai by honorific 'Mas Nganten'. That honorific refers to someone with high social class in the society. In short, the determinant aspect for the woman maid to resort to negative politeness to Gadis Pantai is because Gadis Pantai is more powerful than her (she is her master) and also, they have social class distance (one is a maid, and another is the wife of a Bendara).

Next, frequency of Bald-On Record strategy is second in order. This occurrence is due to the fact that many data are uttered by characters of power in the novel. It is in relation with the notion of determinant of the politeness strategies used in a conversation, which is power as the most prominent determinant, followed by distance of social and affect, and finally on the basis of imposition. Being third in order of frequency in data, positive politeness is motivated by the same factor of power relation, distance, and imposition. The realization of this strategy includes some ways such as speaker using in-group identity makers; attending to the needs and interests of the hearer; speaker seeking agreement with the hearer; and speaker offering the hearer. The first form of positive mentioned sits in the highest frequency of positive politeness. It is due to the fact that many dialogues involve Gadis Pantai and his parents. Therefore, there are many exchanges of in-group identity markers in the utterances such as 'Nak', 'Emak', Bapak', etc.

Finally, the occurrence of hybrid strategy positive-negative is the least in frequency, yet it becomes an interesting part of the finding. This finding is in the same vein with result of study conducted with Miller-Ott and Kelly [19]. They found that it is possible for politeness strategies to occur together in an utterance. Their finding is also on the hybrid of positive and negative politeness. Such a hybrid is an attempt of the speaker to attend to both negative face and the positive face of the speaker. The hybrid of positive and negative means that there is a combination of realizations of the two strategies in an utterance. Example 2 below is a clear depiction of the case.

Example 2:

Woman maid: "Mas Nganten memerlukan sayur lagi? Atau yang lain-lain?"

In example 2, the woman maid uses two different politeness strategies realized in directive offering speech act. First, she resorts to the use of deference "Mas Nganten" on the hearer.

This is a form of a negative strategy. Second, she offers Gadis Pantai to have more vegetables or other kind of food in the dialogue. It means that she adopts offering as a realization of positive strategy. Their co-existence in an utterance is a hybrid strategy, which actually makes the utterance more polite.

\section{Conclusion}

The combination of power relation, social and affect distance, and also imposition of an utterance motivates the choice of politeness strategies used by woman characters in novel 'Gadis Pantai', with the first factor being the most prominent determinant, followed by the second and the latter. In addition to that, it is unfolded that Javanese woman characters resort to Negative Politeness in showing politeness to partner of conversation the most, followed by Bald-On Records, Positive, and Positive Negative. Negative Politeness is realized by giving deference or honorifics to the hearer, lowering own self in order to raise the hearer, apologizing, and asking the hearers of their needs/wants. 
Positive Politeness is realized by using in-group identity marker in conversation, seeking agreement, attending to the needs of the hearer, and offering the hearer. Positive-Negative is realized in the combination of the fashions of the two category such as combining the use of deference on the hearer and the use of offer to the hearer. All in all, all the four politeness strategies found are realized in assertive, directive, commissive, and expressive speech acts.

\section{References}

[1] Hamila, "Masalah-masalah Sosial dalam Novel 'Bumi Manusia' karya Pramoedya Ananta Toer,” J. Humanika, vol. 3, no. 15, 2015.

[2] Rahutami, "Konstruksi Ideologi Karya Sastra Melalui Strategi Wacana: Kajian Linguistik terhadap Novel ‘Bumi Manusia' karya Pramoedya Ananta Toer,” Unpubl. Dr. Diss. Dr. Progr. Linguist. Univ. Gadjah Mada, 2016.

[3] S. S. Mandiri, "Potret Kekejaman Kaum Feodal Terhadap Pribumi Jawa Dalam Novel Gadis Pantai Karya Pramoedya Ananta Toer,” J. Bhs. dan Sastra Indones. Univ. Negeri Yogyakarta, vol. 6, no. 6, pp. 770-785, 2017.

[4] P. Brown and S. C. Levinson, "Politeness: Some Universals in Language Usage (Studies in Interactional Sociolinguistics 4)," TESOL Q., vol. 22, no. 4, p. 660, 1988, doi: 10.2307/3587263.

[5] N. J. Smith-Hefner, "Women and politeness: The Javanese example," Lang. Soc., 1988, doi: $10.1017 / \mathrm{S} 0047404500013087$.

[6] P. Hobbs, "The medium is the message: Politeness strategies in men's and women's voice mail messages," J. Pragmat., 2003, doi: 10.1016/S0378-2166(02)00100-5.

[7] N. Aydınoğlu, "Politeness and Impoliteness Strategies: An Analysis of Gender Differences in Geralyn 1. Horton's Plays," Procedia - Soc. Behav. Sci., 2013, doi: 10.1016/j.sbspro.2013.06.093.

[8] M. Maros and L. Rosli, "Politeness strategies in twitter updates of female english language studies Malaysian undergraduates,” 3L Lang. Linguist. Lit., 2017, doi: 10.17576/3L-20172301-10.

[9] J. R. Searle, "A classification of illocutionary acts," Lang. Soc., 1976, doi: 10.1017/S0047404500006837.

[10] I. Alviah, "Kesantunan Berbahasa Dalam Tuturan Novel Para Priyayi Karya Umar Kayam,” Seloka J. Pendidik. Bhs. dan Sastra Indones., vol. 3, no. 2, pp. 128-135, 2014.

[11] R. Tiani, "Kesantunan Pragmatik Buya Hamka dalam Refleksi Novel Ayah Karya Irfan Hamka," Nusa J. Ilmu Bhs. dan Sastra, vol. 12, no. 1, p. 46, 2017, doi: 10.14710/nusa.12.1.4654.

[12] H. S. Syariah, Martono, "Prinsip Kesantunan Dalam Novel Rindu Karya Tere Liye,” J. Pendidik. dan Pembelajaran Khatulistiwa, vol. 7, pp. 1-13, 2018.

[13] A. Ayuningrum, R. P., and S. S., "an Analysis of Politeness Strategies Applied By the Members," vol. 2, no. 4, pp. 1-8, 2018.

[14] R. Tiani, "NUSA, Vol. 14 No. 2 Mei 2019 Riris Tiani, Strategi Kesantunan Mata Najwa dalam episode Kami Bersama Novel," vol. 14, no. 2, pp. 147-159, 2019.

[15] A. Metiadini, Y. E. Katrini, A. Wijayanti, and U. Tidar, "Kesantunan Berbahasa Tokoh Dilan dalam Novel Milea: Suara dari Dilan Karya Pidi Baiq dan Implementasinya sebagai Bahan Ajar Ulasan Buku Fiksi di SMA," Repetisi Ris. Pendidik. Bhs. dan Sastra Indones., vol. 2, no. 1, pp. 1-20, 2019.

[16] A. Mudassir and I. Adriana, "Kesantunan Berbahasa Dalam Novel Ranah 3 Warna Karya a. Fuadi," GHANCARAN J. Pendidik. Bhs. dan Sastra Indones., vol. 1, no. 2, p. 69, 2020, doi: 10.19105/ghancaran.v1i2.2896.

[17] G. Leech, Principles of Pragmatics. 2016.

[18] F. X. Nadar, "The Prominent Characteristics of Javanese Culture and Their Reflections in Language Use," Humaniora, vol. 19, no. 2, pp. 168-174, 2007.

[19] A. E. Miller-Ott and L. Kelly, "A Politeness Theory Analysis of Cell-Phone Usage in the Presence of Friends," Commun. Stud., vol. 68, no. 2, pp. 190-207, 2017, doi: 10.1080/10510974.2017.1299024. 